\title{
Adiós a Gabriel García Márquez
}

\author{
Farewell to Gabriel García Márquez
}

Adeus Gabriel García Márquez

\section{Carmen Perilli}

universidad nacional de tucumán / CONicet, argentina

Profesora titular de Literatura Latinoamericana en la Universidad Nacional de

Tucumán(UNT); Doctora en Letras por la misma Universidad. Directora de

la revista Telar. Entre sus libros se destacan Imágenes en la mujer en Carpentier

y García Márquez (UNT, 1991), Historiografía y ficción en la narrativa

latinoamericana (UNT, 1995), Países de la memoria y del deseo: Borges y Fuentes

(UNT, 2004) y Catálogo de ángeles mexicanos: Elena Poniatowska (Beatriz

Viterbo, 2006). Es co-compiladora de Fábulas del género (Beatriz Viterbo, 1995) y

Siluetas de papel (Corregidor, 2011). Correo electrónico: carmenperilli@gmail.com

Documento accesible en línea desde la siguiente dirección: http://revistas.javeriana.edu.co

doi:10.11144/Javeriana.CL18-36.aggm

\section{Cómo citar este texto:}

Perilli, Carmen. "Adiós a Gabriel García Márquez". Cuadernos de Literatura 18.36 (2014): 126-129. http://dx.doi.org/10.11144/Javeriana.CL18-36.aggm 
Mi HISTORIA PERSONAL, como la de muchos otros de mi generación, está unida a la lectura de Cien años de soledad. La escena de lectura de la primera edición del barquito, en una siesta interminable en un pueblo de provincia, donde siempre es lunes, me volcó, de modo definitivo, hacia la literatura. A lo largo de estos años las innumerables incursiones en sus páginas dieron lugar a mi trabajo de tesis. Hoy continúan alimentando mi escritura y mis seminarios donde vuelvo una y otra vez sobre el mundo del colombiano. La muerte de Gabriel García Márquez me desafió a recorrer nuevamente el viejo libro. Y volví a ser atrapada en ese mundo sorprendente que, a cada instante, asalta con invenciones de la imaginación y que tiene la virtud de decir la realidad de una manera luminosa. Cada lectura, una aventura incomparable, en un espacio desconocido y misterioso de papel.

Si hay que reivindicar un valor entre los muchos que pueden atribuirse a esta novela es la revalorización del papel de la narración inscripta una y otra vez en un libro que apuesta no solo a la figura del autor sino, y fundamentalmente, a la del lector. El crítico Julio Ortega dice que García Márquez convierte la lectura en el acto novelesco por excelencia. Creo que no hay afirmación más acertada. No solo nos convoca a la lectura sino que la escenifica. ¿Qué es Melquíades sino un lector en una cueva misteriosa y el último Aureliano un lector que llega hasta la muerte y el abandono del hijo con cola de cerdo comido por las hormigas? Ese último Aureliano, despojado del apellido Buendía, lee porque en la lectura se le va la vida y, sobre todo, su identidad. Se lee a sí mismo y lee a los suyos. Aunque la novela comienza con la voz del Aureliano soldado, quien muere al final es el Aureliano lector. El libro nos provoca la voracidad de las grandes narraciones, aquellas que se desean interminables. Nosotros, lectores, nos sentimos incluidos en la ceremonia de la lectura. Macondo desaparece en el instante en el que terminamos la última línea.

El escritor se apropia, sabiamente, de la cadencia de la comarca oral. Desde la primera línea la fábula recoge el hilo de la memoria, pero también el del olvido. El autor está oculto y omnipresente al mismo tiempo. Dentro del relato las escrituras se multiplican, casi siempre en manos de hombres: Melquíades escribe los pergaminos; el Patriarca, sus mapas; Aureliano, poemas de amor; Pietro, sonetos, canciones y cartas; Arcadio, bandos mortales.

Entre las críticas más negativas que he leído hay un libro de Francesco Varanini que denuesta la obra y sus efectos. La acusa de construir una imagen falsa de la realidad, un espejismo encantador y enajenante. Un argumento que resulta insostenible tanto porque la literatura no está obligada con la realidad como con el hecho innegable de que el mundo erigido por García Márquez cala 
hondo en el imaginario cultural e histórico continental. En esta nuestra geografía de utopías y fracasos, donde todo parece recomenzar desde cero,de historias interrumpidas por los ciclones de incontables dictaduras o débiles democracias vivimos con el miedo de sufrir la suerte de Macondo, la ciudad de los sueños del fundador que, en las últimas páginas del libro, es "arrasada por el viento y desterrada de la memoria de los hombres... porque las estirpes condenadas a cien años de soledad no tenían una segunda oportunidad sobre la tierra". Pienso en mi provincia argentina Tucumán. El próspero siglo de industria azucarera que pareció convertirse en polvo, pueblos enteros fueron condenados a desaparecer.

En el discurso del Premio Nobel García Márquez dice que la realidad latinoamericana

no es la del papel, sino que vive con nosotros y determina cada instante de nuestras incontables muertes cotidianas, y [que] sustenta un manantial de creación insaciable, pleno de desdicha y de belleza, del cual este colombiano errante y nostálgico no es más que una cifra más señalada por la suerte. Poetas y mendigos, músicos y profetas, guerreros y malandrines, todas las criaturas de aquella realidad desaforada hemos tenido que pedirle muy poco a la imaginación, porque el desafío mayor para nosotros ha sido la insuficiencia de los recursos convencionales para hacer creíble nuestra vida. Este es, amigos, el nudo de nuestra soledad.

El escritor, en la larga entrevista realizada por Plinio Apuleyo Mendoza, define a la novela como "una representación cifrada de la realidad, una especie de adivinanza del mundo. La realidad que se maneja en una novela es diferente a la realidad de la vida, aunque se apoye en ella. Como ocurre en los sueños".

Entre otras invenciones José Arcadio Buendía fantasea con esa máquina de la memoria que le permita registrar todas las maravillas:

$\mathrm{El}$ artefacto se fundaba en la posibilidad de repasar todas las mañanas, y desde el principio hasta el fin, la totalidad de los conocimientos adquiridos en la vida. Lo imaginaba como un diccionario giratorio que un individuo situado en el eje pudiera operar mediante una manivela, de modo que en pocas horas pasaran frente a sus ojos las nociones más necesarias para vivir.

Los libros son nuestro archivo, artefactos que nos permiten procesar nuestra realidad. García Márquez reivindica el poder mítico del relato que hace posible la conservación de la memoria y el combate contra el olvido. Nos proveyó a lo largo de su vida de distintas máquinas de narrar: el largo poema sobre la soledad y el poder que es El otoño del patriarca; la tragedia inevitable y 
cotidiana que es Crónica de una muerte anunciada; la extensa crónica del amor y la vejez que es El amor en los tiempos del cólera y tantos otros.

$\mathrm{Y}$ así como nos enamoramos de Úrsula y de su carajo para toda la vida, también nos atrapó el estólido coronel dispuesto a comer mierda. Aprendimos a conocer al patriarca, un espantoso y solitario animal y respetar los atrevimientos de Cándida y Delgadina; la precisión de Ángela Vicario para señalar a Santiago Nazar y las mil formas del amor de Fermina Daza. García Márquez nos ha dejado cuentos maravillosos como el del ahogado más hermoso del mundo, crónicas como la de la marquesita de sierpe y relatos cortos magistrales como "el miedo de volar es de machos". Vida y pasión nunca faltarán en esa literatura y eso es lo que importa.

Las figuras de los libros no están encerradas en la letra sino que, como el Quijote, suelen salir a desfacer entuertos. Qué otra cosa son las criaturas de Shakespeare, Cervantes, Borges y García Márquez que demostraciones de lo cercana que pueden estar los sueños de los poetas de la realidad de los hombres. El destino de Gabriel García Márquez, uno de nuestros más grandes confabuladores, es el destino de los hacedores; ser ellos también, un poco, soñados por nosotros, los lectores, que, de una vez y para siempre, hemos sido modificados por la gozosa aventura de su literatura. 